\title{
Increased expression of SNARE proteins and synaptotagmin IV in islets from pregnant rats and in vitro prolactin-treated neonatal islets
}

\author{
DANIEL A CUNHA, ${ }^{1}$ MARIA EC AMARAL,${ }^{1}$ CAROLINA PF CARVALHO,${ }^{2}$ \\ CARLA B COLLARES-BUZATO,${ }^{2}$ EVERARDO M CARNEIRO,${ }^{1}$ and \\ ANTONIO C BOSCHERO ${ }^{1}$
}

\footnotetext{
${ }^{1}$ Departments of Physiology and Biophysics and

${ }^{2}$ Histology and Embryology, Institute of Biology, State University of Campinas (UNICAMP), Campinas, São Paulo, Brazil.
}

\begin{abstract}
During pregnancy and the perinatal period of life, prolactin (PRL) and other lactogenic substances induce adaptation and maturation of the stimulus-secretion coupling system in pancreatic $\beta$-cells. Since the SNARE molecules, SNAP-25, syntaxin 1, VAMP-2, and synaptotagmins participate in insulin secretion, we investigated whether the improved secretory response to glucose during these periods involves alteration in the expression of these proteins. mRNA was extracted from neonatal rat islets cultured for 5 days in the presence of PRL and from pregnant rats $\left(17^{\text {th }}-18^{\text {th }}\right.$ days of pregnancy) and reverse transcribed. The expression of genes was analyzed by semi-quantitative RT-PCR assay. The expression of proteins was analyzed by Western blotting and confocal microscopy. Transcription and expression of all SNARE genes and proteins were increased in islets from pregnant and PRL-treated neonatal rats when compared with controls. The only exception was VAMP-2 production in islets from pregnant rats. Increased mRNA and protein expression of synaptotagmin IV, but not the isoform I, also was observed in islets from pregnant and PRL-treated rats. This effect was not inhibited by wortmannin or PD098059, inhibitors of the PI3-kinase and MAPK pathways, respectively. As revealed by confocal laser microscopy, both syntaxin 1A and synaptotagmin IV were immunolocated in islet cells, including the insulin-containing cells. These results indicate that PRL modulates the final steps of insulin secretion by increasing the expression of proteins involved in membrane fusion.
\end{abstract}

Key terms: insulin, pancreatic islets, pregnant rats, prolactin, SNARE proteins, synaptotagmin.

\section{PROLOGUE}

I met Eduardo Rojas in 1977 at the Experimental Medicine Department, School of Medicine, Free University Brussels/ Belgium. He was attending a seminar with Illani Atwater, his wife, at the invitation of Professor Willy Malaisse. At that time, I was concluding my postdoc at the same institution. Being a Latin American and having a special interest on the pancreatic beta cells electrophisiology, it was easy to engage in conversation, especially in politics and science. In the following semester, before I returned to Brazil, I spent some time learning about beta cells' electrophisiology at East Anglia University in Norwich, where the couple worked. Ten years later, between 1987-1988, I was invited to work with them again, this time at NIDDK, NIH, in Bethesda, Maryland. Then, going back to NIH between 1991-93, always working alongside Illani and Guayo. Eduardo Rojas' intellectual capacity and his work disposition always have impressed me, although his generosity was what I remember the most. He would always welcome me at his home, as well as other fellows from different countries. Helping everyone inside and outside the lab, never 
denying to help resolve daily problems. In conclusion, I want to share my testimony of Eduardo Rojas as great scientist and wonderful human. I have the feeling that I haven't returned in full what Guayo and Illani have done for me and my family during all these years.

\section{INTRODUCTION}

Insulin secretion from pancreatic $\beta$-cells is controlled mainly by blood glucose levels. Hormones, neurotransmitters, and other nutrients also modulate glucose-induced secretion. During pregnancy, insulin secretion is increased due to expansion of the $\beta$-cell mass and a higher level of insulin synthesis to attend to the increased demand (Hellman, 1960; Bone and Taylor, 1976). In rodents, two classes of hormones are increased during the course of pregnancy: growth hormones, including PRL and placental lactogens (Ogren and Talamantes, 1988), and steroid hormones, such as E1, E2, and progesterone (Bartholomeusz et al., 1976; Shaikn, 1971). The exact participation of each hormone in the maturation of the endocrine pancreas still is unclear. However, most of the alterations observed in pancreatic islets during pregnancy can be reproduced in vitro by culturing the islets in the presence of PRL. Steroid hormones do not produce this effect (Sorenson et al., 1993; Boschero et al., 1993). PRL increases $\beta$-cell proliferation (Brelje et al., 1993) and gap-junction coupling among $\beta$-cells (Sorenson et al., 1987; Collares-Buzato et al., 2001), decreases the glucose stimulation threshold, and enhances insulin secretion (Sorensen, 1987). PRL exerts its biological effects mainly by activating the JAK2/ STAT5 pathway (Yamauchi et al., 1998) but also can stimulate IRS1/2, PI3-kinase, and MAPK in different cell lines (Berlanga et al., 1997) and in cultured neonatal rat islets (Amaral et al., 2003).

The soluble N-ethylmaleimide-sensitive factor attached protein receptor (SNARE) is composed of syntaxin, the $25 \mathrm{kDa}$ synaptosomal protein (SNAP-25) and vesicle-associated membrane protein isoform 2 (VAMP-2) and is an important component in the exocytotic machinery. These proteins are expressed in pancreatic islets and $\beta$-cell lines (Wheeler et al., 1996; Gao et al., 2000) and play an important role in $\mathrm{Ca}^{2+}$-induced secretion (Kiraly-Borri et al., 1996). Syntaxin 1, SNAP-25, and VAMP-2 form a coiled-coil structure giving rise to the SNARE complex, apparently responsible for docking of molecules and driving the fusion of vesicles with the plasma membrane (Hanson et al., 1997).

Syntaxin 1 is a crucial component of the membrane fusion machinery, since it can bind to other SNAREs (Martin et al., 1995) and synaptotagmin (Yoshida et al., 1992). Syntaxin 1 binds to a Kv 2.1 channel in $\beta$ cells and inhibits its activity (Pasyk et al., 2004) via interaction with nucleotidebinding folds of SUR1 (Cui et al., 2004). Physical interactions of both Syntaxin 1A and the t-SNARE complex with the C terminus of Kv2.1 also are involved in channel regulation (Tsuk et al., 2005). It also interacts with Munc-18, a SM protein that is thought to prevent formation of the SNARE complex (Pevsner et al., 1994). Syntaxin 1 inhibition in mouse $\beta$-cells decreases insulin secretion (Martin et al., 1996).

An increase in cytosolic $\mathrm{Ca}^{2+}$ is necessary to trigger insulin secretion. However, there is no known $\mathrm{Ca}^{2+}$ sensor in the exocytotic apparatus. The best candidate to exert this function as yet is synaptotagmin. This group of proteins constitutes a large family of $\mathrm{Ca}^{2+}$-binding elements, characterized by the presence of two $\mathrm{C}_{2}$ domains. They were first identified in brain tissue and, more recently, in islets and $\beta$-cell lines (Gao et al., 2000). Binding of $\mathrm{Ca}^{2+}$ to the $\mathrm{C}_{2} \mathrm{~A}$ domain regulates the interaction of synaptotagmin I and syntaxin 1 at high $\mathrm{Ca}^{2+}$ levels (Li et al., 1995). It also has been found that antibodies against the $\mathrm{C}_{2} \mathrm{~A}$ domain of synaptotagmin $\mathrm{I}$ and II in INS-1 cells inhibited $\mathrm{Ca}^{2+}$-induced exocytosis, and mutations in the $\mathrm{C}_{2}$ domain of synaptotagmin II reduced insulin secretion (Lang et al., 1997). Syntaxin 1A also modifies the activity of voltage-gated $\mathrm{Ca}^{2+}$ channels, acting via cytosolic and transmembrane domains (Arien et al., 2003). 
In conclusion, fresh isolated islets from pregnant rats as well as neonatal rat islets cultured in the presence of PRL for 5 days showed increased transcription and expression of syntaxin 1A, SNAP-25, VAMP-2 and synaptotagmin IV genes. Only VAMP-2 production is not increased in islets from pregnant rats. The enhanced expression of these proteins appears to be mediated by a signaling pathway that does not involve PI3-kinase and MAPK cascades.

\section{MATERIALS AND METHODS}

\section{Materials}

SDS-PAGE and immunoblotting were carried out using Bio-Rad systems (Richmond, CA, USA). All chemicals used for immunoblotting were from Sigma (St. Louis, MO, USA) and all reagents used in the experiments for RT-PCR were from Invitrogen (Carlsbad, CA, USA). Rat PRL was supplied by Dr. A. F. Parlow, Harbor University-California at Los Angeles Medical Center and kindly provided by the National Hormone and Pituitary Program of the NIDDK). [125I]insulin and nitrocellulose membranes (Hybond N, 0.45 $\mu \mathrm{m})$ were from Amersham (Buckinghamshire, UK). Anti-syntaxin 1 (mouse monoclonal), anti-synaptotagmin I and IV (goat polyclonal), and anti-VAMP-2 (goat polyclonal) antibodies were from Santa Cruz Biotechnology (Santa Cruz, CA, USA). Anti-SNAP-25 (mouse monoclonal) antibody was from (Sigma).

\section{Islet isolation and culture}

For each set of experiments, islets from 4060 neonatal rats (2-3 days old) were isolated by collagenase digestion of the pancreas in Hanks balanced salt solution and maintained in culture at $37^{\circ} \mathrm{C}$ in a $5 \%$ $\mathrm{CO}_{2}$ /air atmosphere for 5 days. The culture medium consisted of RPMI-1640 supplemented with $10 \%$ fetal bovine serum, $10 \mathrm{mM}$ glucose, $100 \mathrm{IU} / \mathrm{ml}$ penicillin, 100 $\mu \mathrm{g} / \mathrm{ml}$ streptomycin, and PRL $(0.1 \mu \mathrm{g} / \mathrm{ml})$. Wortmannin $(0.1 \mu \mathrm{g} / \mathrm{ml})$ and PD098059
$(0.1 \mu \mathrm{g} / \mathrm{ml})$ were added to the culture medium every day during the 5 days of culture. Adult islets were isolated from female Wistar rats (pregnant or not) by collagenase digestion of the pancreas and separated from pancreatic debris by centrifugation in Ficoll gradients. Islets from pregnant rats were isolated in the 15 th day of pregnancy. The University of Campinas Ethical Committee approved all experiments.

\section{Insulin secretion}

Groups of five islets were first incubated for $45 \mathrm{~min}$ at $37^{\circ} \mathrm{C}$ in Krebs-bicarbonate buffer containing $5.6 \mathrm{mM}$ glucose and equilibrated with $95 \% \mathrm{O}_{2}-5 \% \mathrm{CO}_{2}, \mathrm{pH}$ 7.4. The solution was then replaced with fresh Krebs-bicarbonate buffer, and the islets were incubated for $1 \mathrm{~h}$ with medium containing 2.8 or $16.7 \mathrm{mM}$ glucose. The incubation medium contained $(\mathrm{mM}): \mathrm{NaCl}$ 115, $\mathrm{KCl} 5, \mathrm{NaHCO} 324, \mathrm{CaCl}_{2}$ 2.56, $\mathrm{MgCl}_{2} 1$, and BSA $0.3 \%(\mathrm{w} / \mathrm{v})$. The insulin was measured by RIA using rat insulin as the standard.

\section{Semi-quantitative analysis of $m R N A R T-P C R$}

Total cellular RNA was extracted from groups of islets using Trizol reagent. Reverse transcription was carried out with 2 $\mu \mathrm{g}$ of total RNA using the Moloney murine leukemia virus-reverse transcriptase (Superscript II) and random hexamers according to the manufacturer's instructions (Invitrogen). RT-PCR assays were done using recombinant Taq DNA polymerase with $10 \mathrm{pM}$ of each primer in a final volume of $50 \mu \mathrm{l}$. The primers were designed and synthesized based on the published gene sequence as shown in Table I. The PCR was carried out in a thermal cycler (model 9700, Applied Biosystems) with an initial denaturation step at $94^{\circ} \mathrm{C}$ for 3 min, subjected to variable number of cycles of denaturation at $94^{\circ} \mathrm{C}$ for $30 \mathrm{sec}$, annealing for $30 \mathrm{sec}$, elongation at $72^{\circ} \mathrm{C}$ for $45 \mathrm{sec}$ and a final elongation step at $72^{\circ} \mathrm{C}$ for $7 \mathrm{~min}$. The number of cycles was 26 for $\beta$-actin, 35 for synaptotagmin I, 31 for synaptotagmin IV, 33 for syntaxin $1 \mathrm{~A}, 34$ 
TABLE I

Primers for various genes

\begin{tabular}{|c|c|c|c|c|}
\hline Gene & F or $R^{\mathrm{a}}$ & Primer sequence (5‘-3`) & Melting temperature & Product size \\
\hline \multirow[t]{2}{*}{ Synaptotagmin 1} & $\mathrm{~F}$ & ACTGAGCCAGCCAGTCCTGG & $55^{\circ} \mathrm{C}$ & 640 \\
\hline & $\mathrm{R}$ & ATGTCGTGCTTGGAGAAGCG & & \\
\hline \multirow[t]{2}{*}{ Synaptotagmin 4} & $\mathrm{~F}$ & GCATCTTCAGTGCTTTTGGC & $55^{\circ} \mathrm{C}$ & 711 \\
\hline & $\mathrm{R}$ & TCTCCAATGACATCATCTCT & & \\
\hline \multirow[t]{2}{*}{ SNAP-25 } & $\mathrm{F}$ & GAATTCAATGGCCGAGGACGCAGA & $63^{\circ} \mathrm{C}$ & 621 \\
\hline & $\mathrm{R}$ & ACTTAACCACTTCCCAGCATCTTTGT & & \\
\hline \multirow[t]{2}{*}{ Syntaxin $1 \mathrm{~A}$} & $\mathrm{~F}$ & ATGAAGGACCGAACCCAGGAGC & $59^{\circ} \mathrm{C}$ & 868 \\
\hline & $\mathrm{R}$ & TCTATCCAAAGATGCCCCCGA & & \\
\hline \multirow[t]{2}{*}{ VAMP-2 } & $\mathrm{F}$ & GAATTCAATGTCGGCTACCGCTG & $62^{\circ} \mathrm{C}$ & 354 \\
\hline & $\mathrm{R}$ & GTCGACTTAAGTGCTGAAGTAAACGA & & \\
\hline \multirow[t]{2}{*}{ B-actin } & $\mathrm{F}$ & TGAGCGCAAGTACTCTGTGTGG & $57^{\circ} \mathrm{C}$ & 489 \\
\hline & $\mathrm{R}$ & TTTGGGAGGGTGAGGGACTTC & & \\
\hline
\end{tabular}

${ }^{a} F$, forward primer; $R$, reverse primer.

for SNAP-25, and 39 for VAMP-2. The cycle numbers were defined after titration between 20 and 45 cycles and were within the logarithmic phase of amplification. PCR products were run on $1 \%$ agarose gels, and the DNA was visualized by ethidium bromide staining. The band intensities were determined by digital scanning followed by quantification using Scion Image analysis software.

\section{Tissue extracts and immunoblotting}

After culture, the islets were homogenized in $200 \mu \mathrm{l}$ of solubilization buffer (10\% Triton$\mathrm{X} 100,100 \mathrm{mM}$ Tris $\mathrm{pH}$ 7.4, $10 \mathrm{mM}$ sodium pyrophosphate, $100 \mathrm{mM}$ sodium fluoride, 10 mM EDTA, $10 \mathrm{mM}$ sodium vanadate, and 2 mM PMSF) for $30 \mathrm{~s}$ using a Polytron PT 1200 C homogenizer (Brinkmann Instruments, NY). The tissue extracts were centrifuged at $15,000 \mathrm{~g}$ at $4^{\circ} \mathrm{C}$ for $20 \mathrm{~min}$, and the supernatant was used for protein analysis. Aliquots containing $70 \mu \mathrm{g}$ of islet protein were run on $10 \%$ polyacrylamide gels. Proteins were then transferred to nitrocellulose at $120 \mathrm{~V}$ for $2 \mathrm{~h}$. Non-specific protein binding to nitrocellulose was reduced by preincubating the filter in blocking buffer (3\% BSA, $10 \mathrm{mM}$ Tris, $150 \mathrm{mM} \mathrm{NaCl}$, and $0.02 \%$ Tween 20 ) for $2 \mathrm{~h}$ at $22^{\circ} \mathrm{C}$. The nitrocellulose membranes were then incubated for $4 \mathrm{~h}$ at $22^{\circ} \mathrm{C}$ with anti-syntaxin, anti-VAMP-2, anti-SNAP-25, or antisynaptotagmin I and IV antibodies. The blots were subsequently incubated with $2 \mu \mathrm{Ci}$ of [125I] labeled protein $\mathrm{A}(30 \mu \mathrm{Ci} / \mu \mathrm{g})$ in 10 $\mathrm{ml}$ of blocking buffer for $1 \mathrm{~h}$ at $22^{\circ} \mathrm{C}$. The [125I] labeled protein $\mathrm{A}$ bound to the antibodies was detected by autoradiography using preflashed Kodak film at $-80^{\circ} \mathrm{C}$ for $24-$ $60 \mathrm{~h}$. Band intensities were determined by digital scanning followed by quantification using Scion Image analysis software. 


\section{Immunocytochemistry}

Pools of isolated islets were fixed in paraformaldehyde solution (2\% paraformaldehyde and 10\% saccharose in PBS), gelatin was added at increasing concentration $(5 \%, 10 \%$ and $25 \%)$ and then frozen in n-hexane with liquid nitrogen. Cryostat sections $(6 \mu \mathrm{m})$ of the islet blocks were treated with $0.1 \%$ Triton X-100 (in PBS), incubated for $1 \mathrm{~h}$ with blocking solution (PBS with 5\% skim milk) and then for $12 \mathrm{~h}$ at $4{ }^{\circ} \mathrm{C}$ with the polyclonal synaptotagmin IV or the monoclonal syntaxin 1A antibodies (dilution 1: 50 in PBS with $3 \%$ skim milk). The sections were washed three times in PBS and incubated for $2 \mathrm{~h}$ at room temperature with FITCconjugated secondary antibodies. To determine the co-localization of these proteins and insulin, the samples were further incubated for $2 \mathrm{~h}$ at room temperature with anti-insulin antibody (Dako Cytomation, CA, USA) at a dilution of 1 : 150 in PBS with $3 \%$ skim milk followed by incubation for $2 \mathrm{~h}$ at room temperature with the specific TRITC-conjugated secondary antibody. After washing in PBS, the sections were mounted in a commercial antifading medium (Vectashield - Vector) and analyzed using confocal laser scanning microscopy (Zeiss). Negative controls were incubated with PBS containing 3\% skim milk instead of primary antibodies.

\section{Statistical analysis}

The results were expressed as the mean \pm S.E.M. for the number of experiments (n) indicated. Statistical comparisons were carried out using ANOVA followed by the Turkey-Kramer test. The level of significance was set at $\mathrm{P}<0.05$.

\section{RESULTS}

Expression of syntaxin 1A, VAMP-2, SNAP25 , synaptotagmins $I$ and $I V$ genes in neonatal and adult rat islets

Figure 1 shows that the expression of syntaxin 1A, SNAP-25 and synaptotagmin
IV genes in islets from pregnant rats was significantly higher than control islets $(\mathrm{P}<$ $0.05)$. The expression of syntaxin $1 \mathrm{~A}$, SNAP-25, VAMP-2, and synaptotagmin IV also was increased significantly in neonatal islets cultured for 5 days in the presence of PRL compared with untreated islets (Fig. 2) $(\mathrm{P}<0.05)$. Expression of the VAMP-2 and synaptotagmin I genes in adult islets did not differ from the respective controls (Fig. 1). Expression of the synaptotagmin I gene was not altered in PRL-treated neonatal islets (not shown). The effect of PRL in increasing the expression of syntaxin 1A, SNAP-25, VAMP-2 and synaptotagmin IV genes was not altered by wortmannin or by PD098059, which are inhibitors of the PI3-kinase and of MAPK pathways, respectively. The level of b-actin mRNA (used as an internal control) did not differ between islets from pregnant and control rats or neonatal islets treated with PRL and control islets. The insulin secretion, stimulated by $22.2 \mathrm{mM}$ glucose, in neonatal islets cultured in the absence or presence of PRL was $3.34 \pm 0.41$ and $5.8 \pm$ $0.82 \mathrm{ng} /$ islet.h $(\mathrm{n}=6)$, respectively $(\mathrm{P}<$ $0.05)$. In islets from pregnant and control rats, the insulin secretion, stimulated by 16.7 $\mathrm{mM}$ glucose, was $32.4 \pm 4.3$ and $14.1 \pm 2.5$ and $\mathrm{ng} / \mathrm{ml} . \mathrm{h}(\mathrm{n}=6)$, respectively $(\mathrm{P}<0.05)$. Syntaxin 1B was not expressed in islet tissue (not shown).

Expression of syntaxin 1A, VAMP-2, SNAP25 , and synaptotagmin I and IV proteins

The expression of syntaxin 1A, SNAP-25 and synaptotagmin IV was significantly higher in islets from pregnant rats when compared with controls (Fig. 3) $(\mathrm{P}<0.05)$. Figure 4 shows that expression of the above proteins, and VAMP-2 also was increased in neonatal rat islets treated with PRL when compared with control islets $(\mathrm{P}<0.05)$. Similar to the expression of Vamp-2 and synaptotagmin I in islets from pregnant rats, there was no significant difference between synaptotagmin I expression in neonatal PRL-treated islets and the respective control (Figs. 3 and 4). Tubulin was used as a control probe to assure equal amounts of protein were loaded in the gel (not shown). 

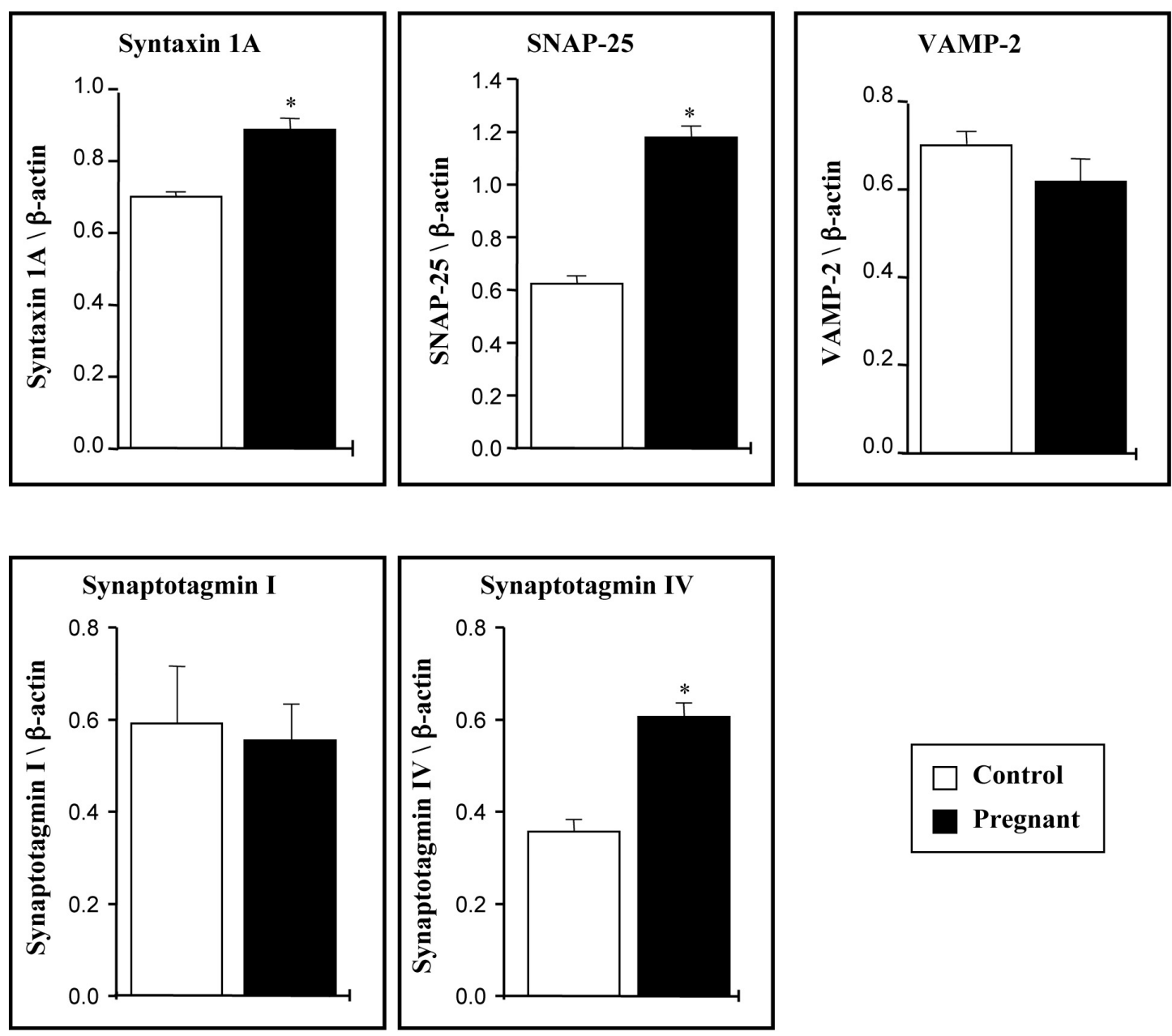

Figure 1. Semi-quantitative RT-PCR analysis of SNARE and synaptotagmin I and IV gene expression in islets from control (empty bars) and pregnant (filled bars) rats. The bars represent the mean \pm S.E.M. of 7 experiments carried out with specific primer pairs (Material and Methods) and normalized against $\beta$-actin. ${ }^{*} \mathrm{P}<0.05$ for control vs. pregnant rats.

Immunocytochemical localization of syntaxin $I A$ and synaptotagmin $I V$ in neonatal rat islets

To determine the subcellular localization of syntaxin $1 \mathrm{~A}$ and synaptotagmin IV, slices of fixed, isolated rat islets were incubated with antibodies against syntaxin $1 \mathrm{~A}$ or synaptotagmin IV and insulin and analyzed by confocal microscopy. As shown in Figure 5, the immunoreaction for synaptotagmin IV presents a punctuate pattern of labeling distributed throughout the cytoplasm. Staining for synaptotagmin IV was observed in all islet cells, including the insulin-containing cells.
We also examined whether PRL treatment affects the expression of synaptotagmin IV. An increase of $27 \%$ in the degree of staining was observed in islets treated with prolactin in comparison with the controls, although no difference in synaptotagmin IV subcellular localization was observed between experimental groups (Fig. 5). Incubation with syntaxin 1A antisera and insulin showed immunoreactivity with this SNARE protein at the plasma membrane of all islet cells, exhibiting stronger immunoreactivity in noninsulin cells (Fig. 5). PRL treatment resulted in an approximately 1.5 -fold increase in syntaxin $1 \mathrm{~A}$ immunoreactivity compared with untreated islets (Fig 5). 

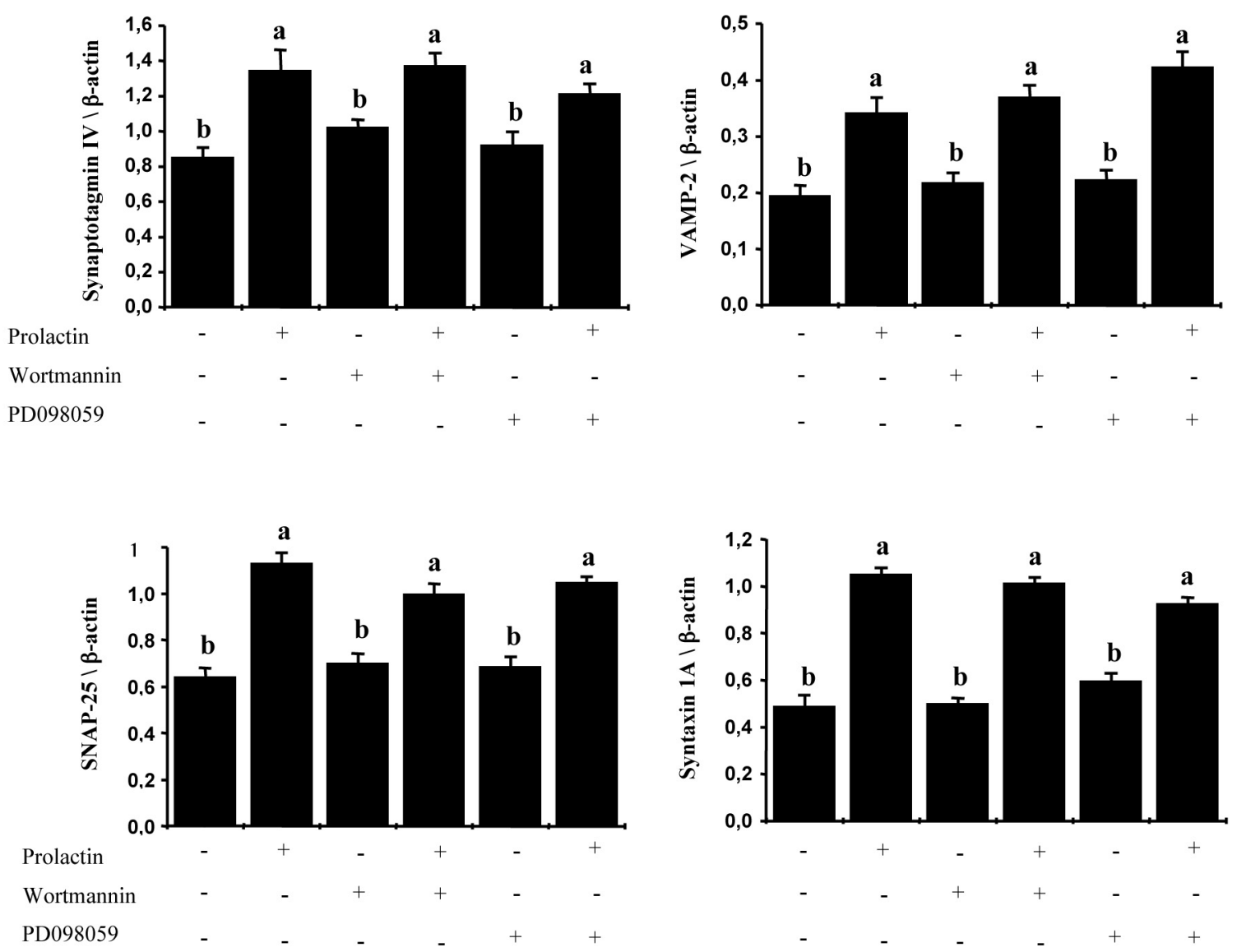

Figure 2. Semi-quantitative RT-PCR analysis of SNARE and synaptotagmin IV gene expressionin islets from neonatal rats. Neonatal rat islets were cultured for 5 days in the absence and/or presence of PRL $(0.1 \mu \mathrm{g} / \mathrm{ml})$, wortmannin $(0.1 \mu \mathrm{g} / \mathrm{ml})$, and PD098059 $(0.1 \mu \mathrm{g} / \mathrm{ml})$, as indicated. The bars represent the mean \pm S.E.M. of 6 experiments done with specific primer sets (Material and Methods) and normalized against $\beta$-actin. The letters above the bars indicate $\mathrm{P}<0.05$.

\section{DISCUSSION}

The kinetics of insulin secretion is an important factor in type-2 diabetes, justifying our efforts to better understand the final steps of insulin secretion (Sheu et al., 2003). In insulin secreting cells, a limited number of vesicles are docked at the internal side of the plasma membrane. During insulin secretion, this pool is release to the extracellular medium and is replaced continuously by granules dispersed in the $\beta$-cell cytoplasm in an ATP-dependent mechanism (Curry et al., 1968).

Docking and subsequent fusion of the insulin-containing vesicles at the plasma membrane is a complex phenomenon that involves multiple proteins including the
SNARE proteins syntaxin, SNAP-25, and Vamp-2 and the $\mathrm{Ca}^{2+-}$ binding protein synaptotagmin (Nagamatsu et al., 1999; Gut et al., 2001).

In this work, we have observed that the SNARE proteins syntaxin 1A and SNAP-25 were increased in islets from pregnant rats when compared with controls. The presence of both syntaxin and SNAP-25 in cells of the endocrine pancreas and neurons has been long known and indicates that both cells share similar mechanisms for $\mathrm{Ca}^{2+}$ regulated exocytosis (Wheeler et al., 1996; Jacobsson et al., 1994).

Formation of the SNARE complex is dependent on the assembly of syntaxin, SNAP25 , and the vesicular protein VAMP-2. However, under low $\left[\mathrm{Ca}^{2+}\right] \mathrm{i}$, the SNARE 
complex formation is inhibited by munc- 18 (Zhang et al., 2000). Increasing concentrations of glucose induce $\beta$-cell depolarization allowing a massive entry of $\mathrm{Ca}^{2+}$ into the cells, increasing the concentration of $\left[\mathrm{Ca}^{2+}\right]$ i. $\mathrm{Ca}^{2+}$ binds to one of the multiple isoforms of synaptotagmin present in $\beta$-cells forming the SNARE complex, which, in turn, favors fusion of the vesicles with the plasma membrane, inducing secretion.

In pregnant rats, we observed an increase in expression of synaptotagmin IV but not synaptotagmin I. However, except for synaptotagmin I, the participation of the various isoforms of synaptotagmins in the secretory process of insulin is still a matter of debate. Synaptotagmins III and VII are claimed to mediate $\mathrm{Ca}^{2+}$-mediated regulation of exocytosis (Gao et al., 2000), whereas others have suggested the participation of synaptotagmin V, VII and VIII in this process (Gut et al., 2001; Saegusa et al., 2002). It is important to keep in mind that all these isoforms, including synaptotagmins I
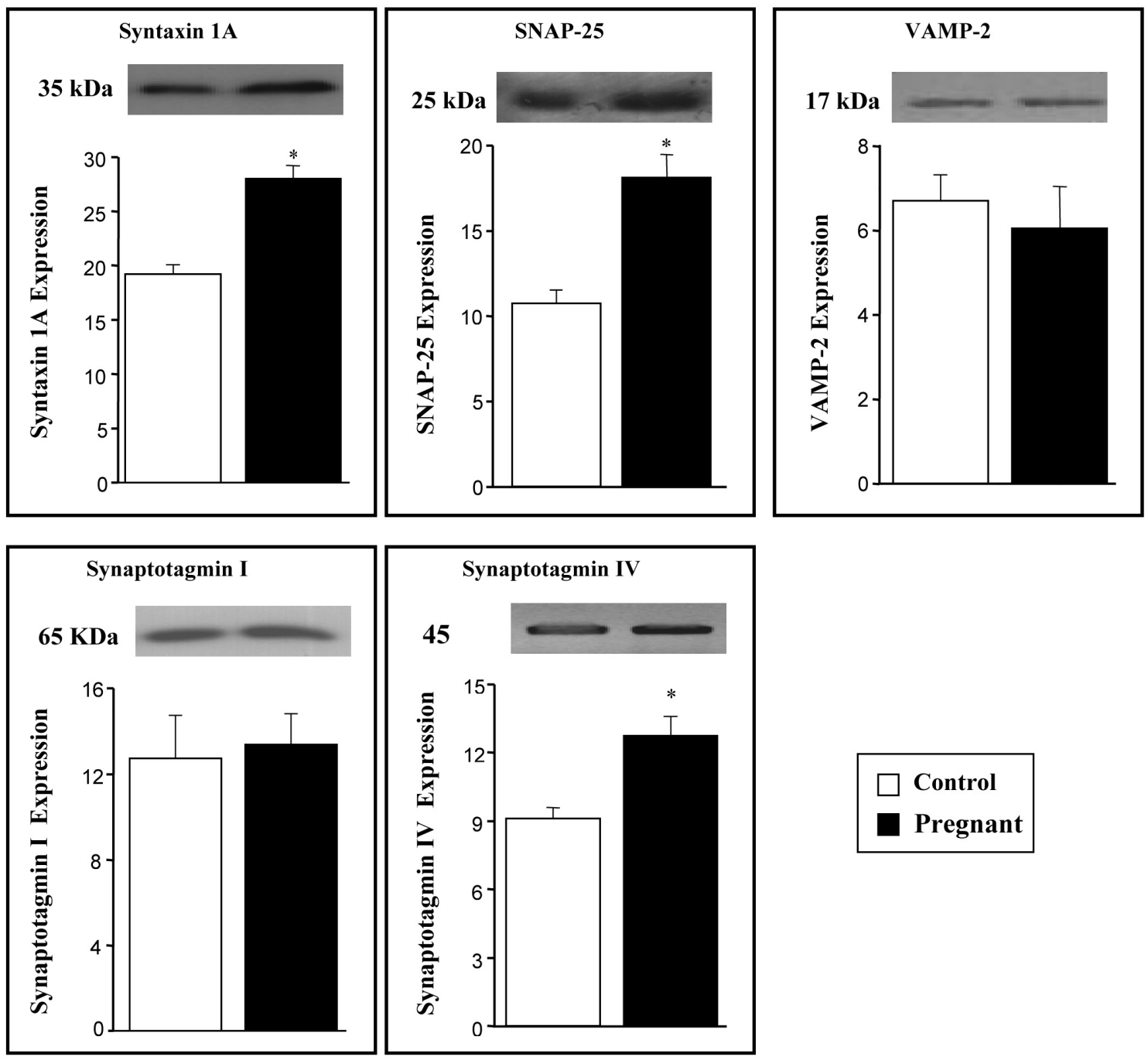

Figure 3. Protein expression of SNARE and synaptotagmin I and IV in islets from adult rats. Equal amounts of protein, extracted from fresh isolated islets from control (empty bars) and pregnant (filled bars) rats, was resolved by SDS-PAGE on $10 \%$ gels and transferred to a nitrocellulose membrane. The proteins were detected with anti-syntaxin 1A, anti-SNAP-25, anti-VAMP-2, and anti-synaptotagmin I and IV antibodies. The values are the mean \pm S.E.M. of 5 experiments. ${ }^{*} \mathrm{P}<$ 0.05 for control vs. pregnant rats. 
and IV, have a $\mathrm{Ca}^{2+}$-binding $\mathrm{C}_{2}$ domain. In our study, we have shown that expression of synaptotagmin IV, but not I, was increased in islets from pregnant rats when compared with controls. Interestingly, synaptotagmin IV appears to be preferentially located adjacent to the TGN complex (Gut et al., 2001), indicating that it does not participate directly in the process of exocytosis as a $\mathrm{Ca}^{2+}$ sensor but rather facilitates the formation and/or distribution of the vesicles containing insulin granules in $\beta$-cells.
In vitro studies have shown that culturing pancreatic islets in the presence of PRL can reproduce most of the alterations observed in the islets during pregnancy (Brelje et al., 1993; Sorenson et al., 1987; Collares-Buzato et al., 2001). In this study, we observed that an increase in the expression of SNARE proteins was reproduced in isolated neonatal rat islets maintained in culture in the presence of PRL, corroborating these observations. In these islets, mRNA and the respective encoded proteins tested, including
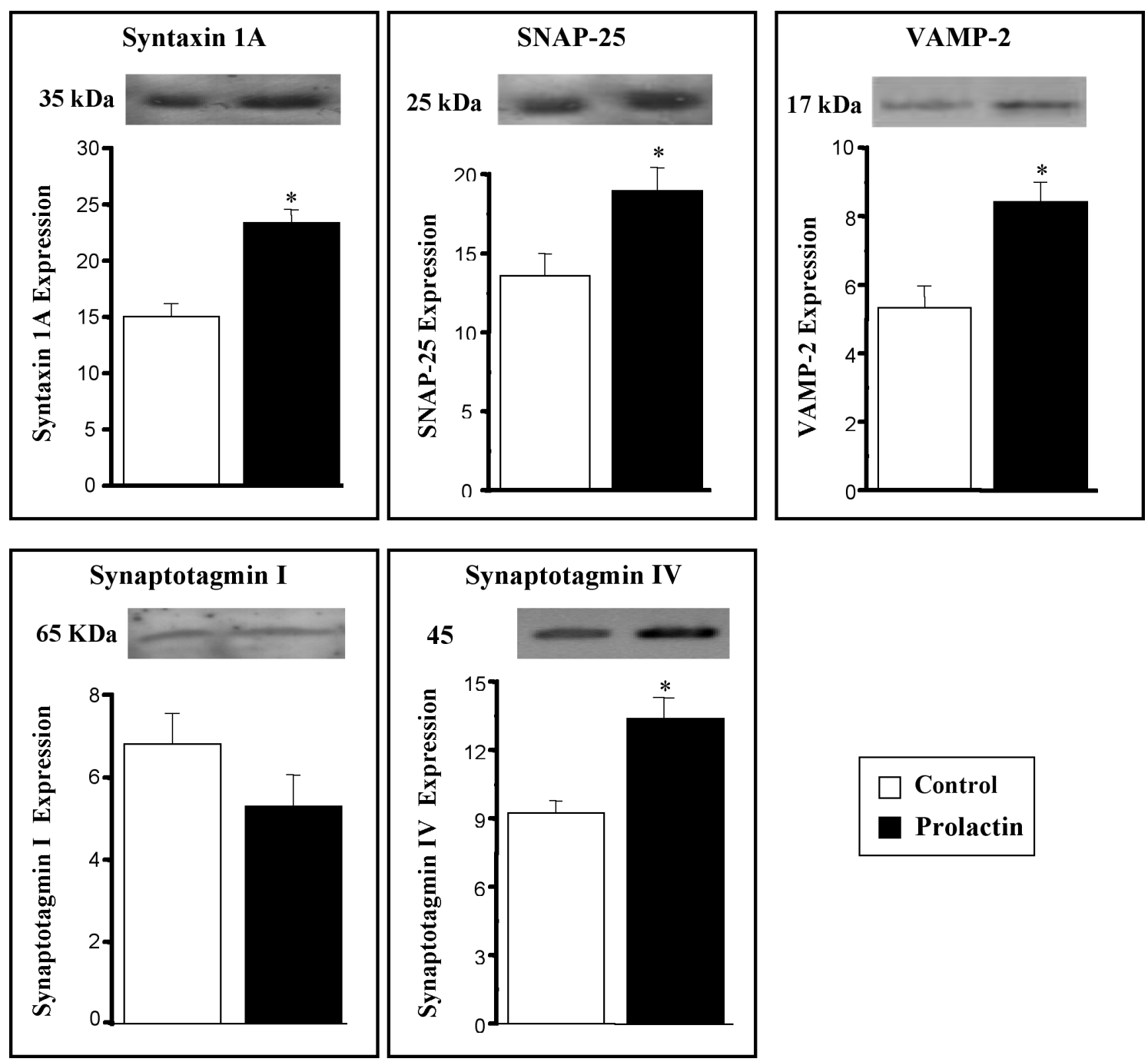

Figure 4. Protein expression of SNARE and synaptotagmin I and IV in islets from neonatal control and PRL-treated islets. Equal amounts of protein, extracted from neonatal islets, cultured for 5 days in the absence (empty bars) or presence of $0.1 \mu \mathrm{g} / \mathrm{ml}$ PRL (filled bars) were resolved by SDSPAGE on $10 \%$ gels and transferred to a nitrocellulose membrane. The proteins were detected with anti-syntaxin 1A, anti-SNAP-25, anti-VAMP-2, and anti-synaptotagmin I and IV antibodies. The values are the mean \pm S.E.M. of 5 experiments. ${ }^{*} \mathrm{P}<0.05$ for control vs. PRL-treated islets. 
VAMP-2, were increased significantly when compared with non-treated islets. The only exception was synaptotagmin I. These results clearly indicate the participation of PRL in the maturation of the exocytotic process.

Since PRL also stimulates the IRSs/PI3kinase and SHC/ERK pathways in neonatal rat islets (Amaral et al., 2003), we exposed the islets to PRL and wortmannin or PD098059, inhibitors of the PI3-kinase and MAPK pathways, respectively, for 5 days. Both agents failed to inhibit the effect of PRL on expression of the above proteins, indicating that the PI3-kinase pathway and MAPK cascades are not involved. In contrast, wortmannin and PD098059 inhibited the PRL-induced increase in transcription of insulin mRNA in neonatal cultured rat islets (data not shown), raising the possibility that PRL stimulates expression of different proteins using distinct signaling pathways.

The presence of syntaxin $1 \mathrm{~A}$ in different cell types of the pancreatic islets was confirmed by confocal microscopy. This protein was located preferentially adjacent to the plasma membrane and co-localized with insulin positive cells in control and PRLtreated neonatal islets. The presence and localization of synaptotagmin IV also was confirmed in cultured islets in the absence or presence of PRL. Synaptotagmin IV was distributed throughout the cytoplasm of the islet cells, including the insulin-positive cells, agreeing with previous work suggesting that synaptotagmin IV is located close to the TGN complex (Gut et al., 2001).
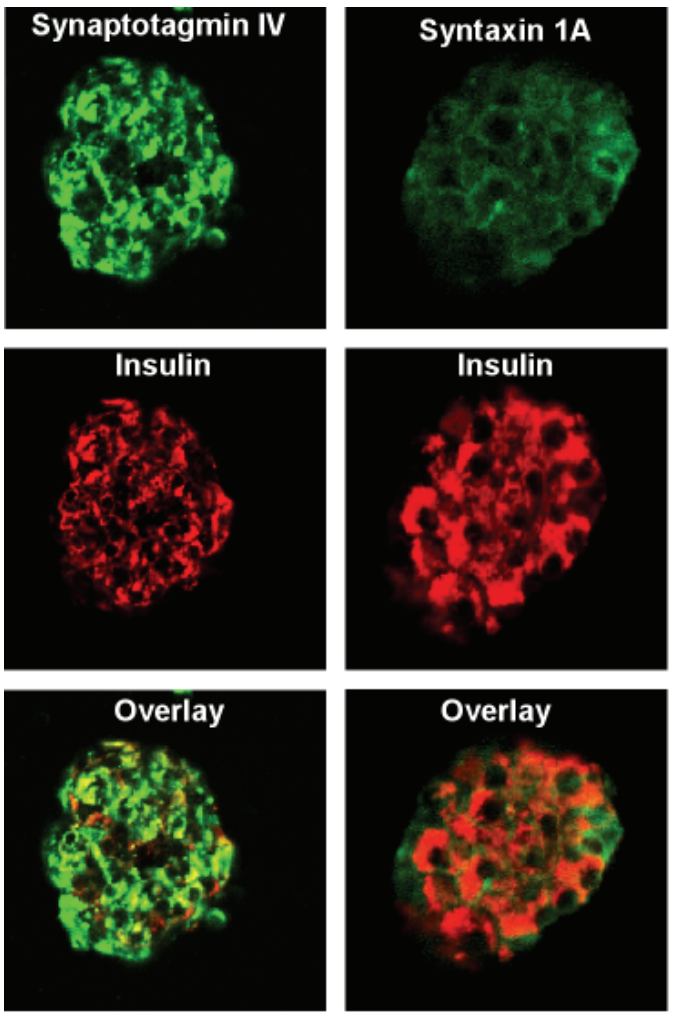
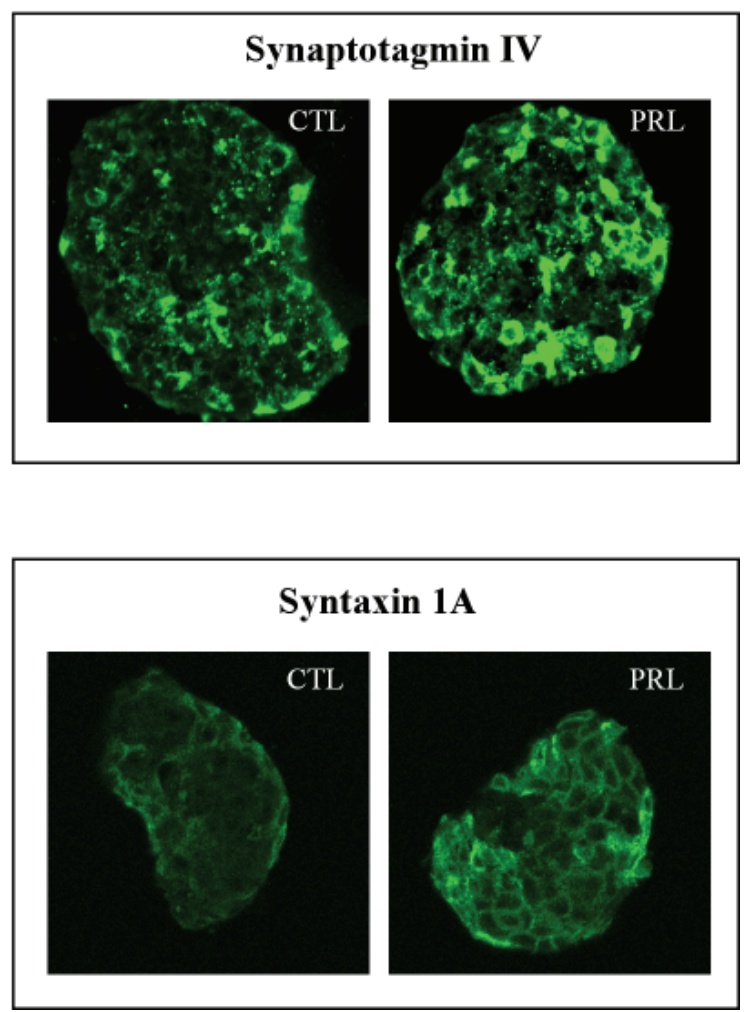

Figure 5. "En face" (X-Z) confocal images showing immunofluorescence staining of syntaxin 1A and synaptotagmin IV in isolated neonatal rat islets cultured for 5 days in absence or presence of PRL. Note that synaptotagmin IV was immunolocated throughout the cytoplasm whereas the immunolabelling for syntaxin $1 \mathrm{~A}$ was confined to the cytoplasmic membrane of islet cells. The PRL-treated islets displayed a slightly brighter immunoreaction for both proteins when compared with controls. Dual immunofluorescence staining of syntaxin 1A or synaptotagmin IV and insulin showed that these proteins are expressed by $\beta$-cells as well as non $\beta$-cells. 
In conclusion, these results indicate that the increase in insulin secretion in islets from pregnant rats involves an increase in expression of various proteins that participate in the exocytotic process. The increase in the expression of these proteins in neonatal islets produced by PRL indicates that this hormone plays an important role in such a process.

\section{ACKNOWLEDGEMENTS}

The authors thank L.D. Teixeira for technical assistance and L.A. Pirrit for editing the English. This work was supported partially by the Brazilian foundations FAPESP, CAPES, and CNPq/ PRONEX.

\section{REFERENCES}

AMARAL ME, UENO M, CARVALHEIRA JB, CARNEIRO EM, VELLOSO LA, SAAD MJ, BOSCHERO AC (2003) Prolactin-signal transduction in neonatal rat pancreatic islets and interaction with the insulin-signaling pathway. Horm Metab Res 35: 282289

ARIEN H, WISER O, ARKIN IT, LEONOV H, ATLAS D (2003) Syntaxin 1A modulates the voltage-gated Ltype calcium channel $(\mathrm{Ca}(\mathrm{v}) 1.2)$ in a cooperative manner. J Biol Chem 278: 29231-29239.

BARTHOLOMEUSZ RK, BRUCE NW, MARTIN CE, HARTMANN PE (1976) Serial measurement of arterial plasma progesterone levels throughout gestation and parturition in individual rats. Acta Endocrinol (Copenh) 82: 436-445

BERLANGA JJ, GUALILLO O, BUTEAU H, APPLANAT M, KELLY PA, EDERY M (1997) Prolactin activates tyrosyl phosphorylation of insulin receptor substrate 1 and phosphatidylinositol-3-OH kinase. J Biol Chem 272: 2050-2052

BONE AJ, TAYLOR KW (1976) Metabolic adaptation to pregnancy shown by increased biosynthesis of insulin in islets of Langerhans isolated from pregnant rats. Nature 262: 501-502

BOSCHERO AC, CREPALDI SC, CARNEIRO EM, DELATTRE E, ATWATER I (1993) Prolactin induces maturation of glucose sensing mechanisms in cultured neonatal rat islets. Endocrinology 133: 515-520

BRELJE TC, SCHARP DW, LACY PE, OGREN L, TALAMANTES F, ROBERTSON M, FRIESEN HG, SORENSON RL (1993) Effect of homologous placental lactogens, prolactins, and growth hormones on islet B-cell division and insulin secretion in rat, mouse, and human islets: Implication for placental lactogen regulation of islet function during pregnancy. Endocrinology 132: 879-887

COLLARES-BUZATO CB, LEITE AR, BOSCHERO AC (2001) Modulation of gap and adherens junctional proteins in cultured neonatal pancreatic islets. Pancreas 23: $177-185$
CUI N, KANG Y, HE Y, LEUNG YM, XIE H, PASYK EA, GAO X, SHEU L, HANSEN JB, WAHLl P, TSUSHIMA RG, GAISANO HY (2004) H3 domain of syntaxin $1 \mathrm{~A}$ inhibits KATP channels by its actions on the sulfonylurea receptor 1 nucleotide-binding folds- 1 and -2. J Biol Chem 279: 53259-53265

CURRY DL, BENNET LL, GRODSKY GM (1968) Dynamics of insulin secretion by the perfused rat pancreas. Endocrinology 83: 572-584

GAO Z, REAVEY-CANTWELL J, YOUNG RA, JEGIER P, WOLF BA (2000) Synaptotagmin III/VII isoforms mediate $\mathrm{Ca}^{2+}$-induced insulin secretion in pancreatic islet $\beta$-cells. J Biol Chem 275: 36079-36085

GUT A, KIRALY CE, FUKUDA M, MIKOSHIBA K, WOLLHEIM CB, LANG J (2001) Expression and localisation of synaptotagmin isoforms in endocrine beta-cells: Their function in insulin exocytosis. J Cell Sci 114: 1709-1716

HANSON PI, ROTH R, MORISAKI H, JAHN R, HEUSER JE (1997) Structure and conformational changes in NSF and its membrane receptor complexes visualized by quick-freeze/deep-etch electron microscopy. Cell 90: $523-535$

HELLMAN B (1960) The islets of Langerhans in the rat during pregnancy and lactation, with special reference to the changes in the $\mathrm{B} / \mathrm{A}$ cell ratio. Acta Obstet Gynecol Scand 39: 331-342

JACOBSSON G, BEAN AJ, SCHELLER RH, JUNTTIBERGGREN L, DEENEY JT, BERGGREN PO, MEISTER B (1994) Identification of synaptic proteins and their isoform mRNAs in compartments of pancreatic endocrine cells. Proc Natl Acad Sci USA 91: 12487-12491

KIRALY-BORRI CE, MORGAN A, BURGOYNE RD, WELLER U, WOLLHEIM CB, LANG J (1996) Soluble N-ethylmaleimide-sensitive factor attachment protein and $\mathrm{N}$-ethylmaleimide-insensitive factors are required for $\mathrm{Ca}^{2+}$-stimulated exocytosis of insulin. Biochem J 314: 199-203

LANG J, FUKUDA M, ZHANG H, MIKOSHIBA K, WOLLHEIM CB (1997) The first C2 domain of synaptotagmin is required for exocytosis of insulin from pancreatic beta-cells: Action of synaptotagmin at low micromolar calcium. J EMBO 16: 5837-5846

LI C, ULLRICH B, ZHANG JZ, ANDERSON RG, BROSE $\mathrm{N}$, SUDHOF TC (1995) Ca(2+)-dependent and independent activities of neural and non-neural synaptotagmins. Nature 375: 594-599

MARTIN F, MOYA F, GUTIÉRREZ LM, REIG JA, SORIA B (1995) Role of syntaxin in mouse pancreatic beta cells. Diabetologia 38: 860-863

MARTIN F, SALINAS E, VÁZQUEZ J, SORIA B, REIG JA (1996) Inhibition of insulin release by synthetic peptides shows that the $\mathrm{H} 3$ region at the $\mathrm{C}$-terminal domain of syntaxin-1 is crucial for $\mathrm{Ca}(2+)$ - but not for guanosine 5'-[gamma-thio]triphosphate-induced secretion. Biochem J 320: 201-205

NAGAMATSU S, NAKAMICHI Y, OZAWA S, ISHIDA H (1999) Decreased expression of t-SNARE, syntaxin 1, and SNAP-25 in pancreatic beta-cells is involved in impaired insulin secretion from diabetic GK rat islets: Restoration of decreased t-SNARE proteins improves impaired insulin secretion. Diabetes 48: 2367-2373

OGREN L, TALAMANTES F (1988) Prolactins of pregnancy and their cellular source. Int Rev Cytol 112: $1-65$

PASYK EA, KANG Y, HUANG X, CUI N, SHEU L, GAISANO HY (2004) Syntaxin-1A binds the nucleotidebinding folds of sulphonylurea receptor 1 to regulate the KATP channel. J Biol Chem 279: 4234-4240 
PEVSNER J, HSU SC, BRAUN JEA, CALAKOS N, TING AE, BENNET ME, SCHELLER RH (1994) Specificity and regulation of a synaptic vesicle docking complex. Neuron 13: 353-361

SAEGUSA C, FUKUDA M, MIKOSHIBA K (2002) Synaptotagmin V is targeted to dense-core vesicles that undergo calcium-dependent exocytosis in PC12 cells. J Biol Chem 277: 24499-24505

SHAIKN AA (1971) Estrone and estradiol levels in the ovarian venous blood from rats during the estrous cycle and pregnancy. Biol Reprod 5: 297-307

SHEU L, PASYK EA, JI J, HUANG $X, G A O X$, VAROQUEAUX F, BROSE N, GAISA HY (2003) Regulation of insulin exocytosis by Munc13-1. J Biol Chem 278: 27556-27563

SORENSON RL, BRELJE TC, HEGRE OD, MARSHALL S, ANAYA P, SHERIDAN JD (1987) Prolactin (in vitro) decreases the glucose stimulation threshold, enhances insulin secretion, and increases dye coupling among islet B cells. Endocrinology 121: 1447-1453

SORENSON RL, BRELJE TC, ROTH C (1993) Effects of steroid and lactogenic hormones on islets of Langerhans: A new hypothesis for the role of pregnancy steroids in the adaptation of islets to pregnancy. Endocrinology 133: 2227-2234

TSUK S, MICHAELEVSKI I, BENTLEY GN, JOHO RH, CHIKVASHVILI D (2005) Lotan I. Kv2.1 channel activation and inactivation is influenced by physical interactions of both syntaxin $1 \mathrm{~A}$ and the syntaxin $1 \mathrm{~A} /$ soluble N-ethylmaleimide-sensitive factor-25 (tSNARE) complex with the $\mathrm{C}$ terminus of the channel. Mol Pharmacol 67: 480-488

WHEELER MB, SHEU L, GHAI M, BOUQUILLON A, GRONDIN G, WELLER U, BEAUDOIN AR, BENNETT MK, TRIMBLE WS, GAISANO HY (1996) Characterization of SNARE protein expression in beta cell lines and pancreatic islets. Endocrinology 137: $1340-1348$

YAMAUCHI T, KABURAGI Y, UEKI K, TSUJI Y, STARK GR, KERR IM, TSUSHIMA T, AKANUMA Y, KOMURO I, TOBE K, YAZAKI Y, KADOWAKI T (1998) Growth hormone and prolactin stimulate tyrosine phosphorylation of insulin receptor substrate$1,-2$, and -3 , their association with p85 phosphatidylinositol 3-kinase (PI3-kinase), and concomitantly PI3-kinase activation via JAK2 kinase. J Biol Chem 273: 15719-15726

YOSHIDA A, OHO C, OMORI A, KUWAHARA R, ITO T, TAKAHASHI M (1992) HPC-1 is associated with synaptotagmin and omega-conotoxin receptor. J Biol Chem 267: 24925-24928

ZHANG W, EFANOV A, YANG SN, FRIED G, KOLARE $\mathrm{S}$, BROWN H, ZAITSEV S, BERGGREN PO, MEISTER B (2000) Munc-18 associates with syntaxin and serves as a negative regulator of exocytosis in the pancreatic beta-cell. J Biol Chem 275: 41521-41527 